\title{
Aktivitas Antioksidan dan Kandungan Fenolik Total Daun Zodia (Evodia suaveolens)
}

\author{
Khoirul Ngibad $^{\mathrm{a}^{*}}$ dan Lilla Puji Lestari ${ }^{\mathrm{b}}$ \\ ${ }^{a}$ Jurusan D3 Teknologi Laboratorium Medik, Fakultas Ilmu Kesehatan, Universitas Maarif Hasyim Latif, \\ Sidoarjo, Jl. Raya Ngelom Megare No.30, Ngelom, Kec. Taman, Kabupaten Sidoarjo, Jawa Timur 61257 \\ Telepon: (031) 7885205 \\ ${ }^{b}$ Jurusan D4 Teknologi Laboratorium Medik, Fakultas Ilmu Kesehatan, Universitas Maarif Hasyim Latif, \\ Sidoarjo, Jl. Raya Ngelom Megare No.30, Ngelom, Kec. Taman, Kabupaten Sidoarjo, Jawa Timur 61257 \\ Telepon: (031) 7885205 \\ * Corresponding author \\ E-mail : khoirul_ngibad@dosen.umaha.ac.id \\ DOI: 10.20961/alchemy.16.1.35580.94-109
}

Received 13 November 2019, Accepted 19 February 2020, Published 01 March 2020

\begin{abstract}
ABSTRAK
Senyawa dengan radikal bebas merupakan senyawa yang mempunyai satu atau lebih elektron tidak berpasangan yang dapat merusak sel dan jaringan jika terakumulasi dalam tubuh manusia. Antioksidan dapat berfungsi untuk menginaktivasi reaksi oksidasi dan mencegah terbentuknya radikal tetapi antioksidan sintetik dapat menyebabkan karsinogen. Oleh karena itu, antioksidan yang terkandung dalam sumber alami perlu diteliti lebih lanjut. Salah satunya adalah tanaman zodia (Evodia suaveolens). Tujuan dari penelitian ini adalah untuk mengetahui nilai aktivitas antioksidan dari ekstrak metanol, etil asetat, dan diklorometana dari daun tanaman zodia yang dinyatakan dengan $\mathrm{IC}_{50}$ (inhibitory concentration) dan untuk mengetahui kadar fenolik total dari ekstrak daun zodia. Serbuk daun zodia dimaserasi menggunakan tiga pelarut, yaitu metanol, etil asetat, dan diklorometana secara terpisah. Penentuan aktivitas antioksidan dilakukan dengan uji penangkapan radikal DPPH (2,2-difenill-1-pikrilhidrazil) sedangkan penentuan kandungan fenolik total dilakukan menggunakan metode spektrofotometri. Nilai aktivitas antioksidan yang dinyatakan dengan $\mathrm{IC}_{50}$ dari ekstrak metanol, etil asetat, dan diklorometana dari daun zodia berturut-turut adalah 170, 124, dan 409 ppm. Kadar fenolik total dari ekstrak metanol, etil asetat, dan diklorometana dari daun zodia berturut-turut adalah 0,02430; 0,01183; dan 0,00930 mg GAE/g.
\end{abstract}

Kata kunci: antioksidan secara in-vitro, DPPH, Evodia suaveolens, kadar fenolik, maserasi

\begin{abstract}
Antioxidant Activity and Total Phenolic Content of Zodia Leaves (Evodia suaveolens). The compounds with free radicals are compounds that have one or more unpaired electrons which can damage cells and tissues if they was accumulated in the human body. Antioxidants can act to inactivate oxidation reactions and prevent the formation of radicals but synthetic antioxidants can cause carcinogens. Therefore, antioxidants containing in natural sources need to be investigated. One of them is the zodia (Evodia suaveolens) plant. The purpose of this study was to determine the value of antioxidant activity of methanol, ethyl acetate, and dichloromethane extract from the leaves of the zodia plant in $\mathrm{IC}_{50}$ (inhibitory concentration) and to determine the total phenolic content of zodia leaf extract. Zodia leaves powder was macerated using three solvents, namely: methanol, ethyl acetate, and dichloromethane, separately. Determination of antioxidant activity was carried out by DPPH (2,2-diphenyl-1-picrilhydrazyl) radical
\end{abstract}


catching test and the determination of total phenolic content was carried out using spectrophotometric methods. The antioxidant activity values expressed by $\mathrm{IC}_{50}$ from methanol, ethyl acetate, and dichloromethane extracts from zodia leaves were 170, 124, and 409 ppm, respectively. Total phenolic concentrations of methanol, ethyl acetate, and dichloromethane extracts from zodia leaves were 0.02430, 0.01183 , and $0.00930 \mathrm{mg} \mathrm{GAE} / \mathrm{g}$.

Keywords: DPPH, Evodia suaveolens, in-vitro antioxidants, maceration, phenolic levels

\section{PENDAHULUAN}

Radikal bebas merupakan senyawa yang mempunyai satu atau lebih elektron tidak berpasangan. Radikal bebas tersebut dapat dihasilkan oleh metabolisme sel yang normal dalam tubuh manusia atau bisa juga berasal dari sumber luar seperti polusi, asap rokok, radiasi dan obat yang dapat merusak sel dan jaringan jika terakumulasi dalam tubuh manusia (Paliwal et al., 2017). Reactive oxygen species (ROSs) merupakan jenis radikal bebas yang dapat mengoksidasi protein, lemak, DNA dan dapat menginisiasi terjadinya penyakit kronik atau degeneratif seperti: kanker, diabetes dan penyakit kardiovaskuler (Aktumsek et al., 2013).

Antioksidan mampu menginaktivasi reaksi oksidasi dan mencegah terbentuknya radikal bebas. Antioksidan bisa berupa sintetik dan alami. Antioksidan sintetik yang sangat efektif dan secara luas telah digunakan adalah butylated hydroxytoluene (BHT) atau butylated hydroxyanisole (BHA). Akan tetapi, keduanya dapat menyebabkan efek karsinogen yang berbahaya (Hidayati et al., 2017). Oleh karena itu, banyak studi mengenai potensi antioksidan alami yang sudah dilakukan (Zou, 2004; Liu et al., 2013).

Indonesia mempunyai berbagai jenis tanaman yang dapat tumbuh dari Sabang sampai Merauke. Salah satunya adalah tanaman zodia (Evodia suaveolens) yang dikenal oleh masyarakat sebagai tanaman hias dan pengusir nyamuk (Isrianto, 2016). Kandungan senyawa minyak atsiri dalam daun zodia telah diteliti menggunakan Gas CromatographyMass Spectrometry (GC-MS). Senyawa-senyawa terdapat dalam daun zodia meliputi: limonene, menthofuran, (5H)-benzofurano-ne, 4(5H)-benzofuranone, myrtenoic acid, copaene, $\quad$-mentha-1(7),8-dien-9-ol, caryophyllene, valencene, $\beta$-himachalene, $a$ curcumene, cadinene, 3,5-octadiene, 2,4,6-trimethoxytoluene, 4,6-hetadienoic acid, humulane-1,6-dien-3-ol, longifolenaldehyde, 4-hydroxy- $\beta$-ionone, trans-squalene, dan vitamine E. Metode esktraksi yang digunakan adalah maserasi menggunakan pelarut etanol selama 3 x 24 jam (Handayani and Nurcahyanti, 2014). Selain itu, kandungan senyawa aktif dalam ekstrak etanol daun zodia (Evodia suaveolens) juga telah diidentifikasi menggunakan GC-MS. Kandungan senyawa aktif dalam ekstrak etanol daun zodia tersebut 
meliputi : menthofuran; evodone; bicyclopentene; delta-selinene; 3,5,7-octatrien-2-ol, aromadendrene oxide 2; alpha-bisabolol; 2,4-dimethyl-2,4- heptadienal; phytol; squalene; beta-tocopherol; D-alpha-tocopherol; stigmasta-5,23-dien-3.beta.-ol; (23S)-ethylcholest-5en-3.beta.ol; 24,25-dihydrolanosterol; lanosterol; dan obtusifoliol (Sanora et al., 2019).

Uji toksisitas ekstrak metanol daun zodia telah dilakukan menggunakan metode Brine Shrimp Lethality Test (BSLT). Hasil LC L $_{50}$ yang diperoleh adalah sebesar 131,34 ppm (bersifat toksik) (Lestari et al., 2015). Hasil skrining fitokimia secara kualitatif dari ekstrak metanol daun zodia menunjukkan bahwa daun zodia mengandung golongan senyawa alkaloid, flavonoid, tanin dan saponin. Golongan senyawa flavonoid atau polifenol mempunyai kemampuan untuk mencegah terjadinya reaksi autooksidasi dengan cara memberikan satu elektron dari senyawa flavonoid tesebut kepada elektron tidak berpasangan dari senyawa radikal bebas, akibatnya jumlah radikal bebas dapat diturunkan (Porkony et al., 2001).

Penelitian mengenai potensi antioksidan dari daun zodia belum dilakukan. Dengan demikian, penelitian ini bertujuan untuk menentukan aktivitas antioksidan daun zodia menggunakan metode DPPH (2,2-difenil-1-pikrilhidrazil) dengan variasi pelarut untuk proses maserasi yang meliputi metanol, etil asetat, dan diklorometana. Variasi pelarut yang digunakan dalam proses maserasi tersebut bertujuan untuk mengetahui potensi ekstrak daun zodia sebagai antioksidan menggunakan pelarut yang bersifat polar (metanol), semipolar (etil asetat) dan nonpolar (diklorometana).

\section{METODE PENELITIAN}

Alat yang digunakan dalam penelitian ini meliputi: Rotary evaporator vacuum (Eyela®) dan spektrofotometer UV-Vis (SHIMADZHU®). Bahan yang digunakan dalam penilitian ini antara lain: serbuk simplisia daun zodia (Evodia suaveolens) yang diperoleh dari kota Batu, Jawa Timur, Indonesia. Pelarut metanol, etil asetat, diklorometana, dan etanol serta DPPH (2,2-difenil-1-pikrilhidrazil) dibeli dari Sigma Aldrich. Vitamin C dari Sigma Aldrich digunakan sebagai standar antioksidan. Semua reagen merupakan analytical grade.

\section{Persiapan Sampel}

Daun zodia segar ditimbang, dicuci dengan air bersih dan dipotong kecil-kecil. Sampel dikeringkan dengan diangin-anginkan. Kemudian sampel diblender dan diayak sampai terbentuk serbuk dengan ukuran 60 mesh. 


\section{Pembuatan Ekstrak Daun Zodia}

Sebanyak 10 g serbuk dimaserasi menggunakan pelarut metanol sebanyak $250 \mathrm{~mL}$ pada suhu kamar. Proses maserasi dilakukan selama 24 jam kemudian disaring hingga diperoleh filtrat dan ampas. Filtrat dimasukan dalam wadah sedangkan ampas dimaserasi kembali menggunakan pelarut metanol yang baru sebanyak $250 \mathrm{~mL}$. Proses maserasi dihentikan ketika ampas sudah berwarna pucat. Kemudian filtrat dikumpulkan untuk dipekatkan dengan rotary evaporator sampai diperoleh ekstrak pekat. Perlakuan yang sama juga diterapkan pada proses maserasi menggunakan pelarut etil asetat dan diklorometana. Rendemen dari masing-masing ekstrak dihitung menggunakan persamaan (1).

$$
\% \text { Rendemen }=\frac{\text { berat ekstrak }(\mathrm{g})}{\text { berat sampel }(\mathrm{g})} \times 100 \%
$$

\section{Persiapan Larutan Sampel Uji dan Standar Antioksidan}

Larutan sampel uji ekstrak metanol, ekstrak etil asetat daun zodia dan vitamin C dibuat dalam konsentrasi (20, 40, 60, 80, dan 100) mg/L masing-masing sebanyak $50 \mathrm{~mL}$. Di sisi lain, larutan sampel uji ekstrak diklorometana daun zodia dibuat dalam konsentrasi (50, 100, 200, 300, dan 500) mg/L masing-masing sebanyak $50 \mathrm{~mL}$.

\section{Uji Antioksidan menggunakan Metode DPPH}

Masing-masing larutan sampel uji dan standar antioksidan dipipet sebanyak 0,25 $\mathrm{mL}$ dan dicampur dengan larutan DPPH $6 \times 10^{-5} \mathrm{M}$ sebanyak $5 \mathrm{~mL}$ dalam tabung reaksi. Kemudian divortex selama 1 menit. Setelah inkubasi selama 30 menit pada suhu kamar, absorbansi campuran reaksi diukur pada panjang gelombang $515 \mathrm{~nm}$ menggunakan spektrofotometer untuk mendapatkan nilai absorbansi sampel. Larutan blanko yang terdiri dari metanol dalam larutan DPPH disiapkan dan diukur pada panjang gelombang yang sama untuk mendapatkan nilai absorbansi kontrol. Percobaan dilakukan dengan 3 kali pengulangan. Aktivitas antioksidan dihitung menggunakan persamaan (2).

$$
\text { Aktivitas antioksidan }(\%)=\frac{\text { Absorbansi kontrol-Absorbasi sampel }}{\text { Absorbansi kontrol }} \times 100 \%
$$

Selanjutnya, dibuat grafik hubungan antara konsentrasi sampel (sumbu x) dan persen penghambatan radikal DPPH (sumbu y). Perhitungan nilai $\mathrm{IC}_{50}$ didasarkan pada rumus persamaan regresi linear.

\section{Penentuan Kadar Fenolik Total}

Kandungan fenolik total ditentukan dengan metode spektrofotometri visibel dengan cara sebagai berikut: sejumlah ekstrak atau fraksi uji dimasukkan ke dalam labu takar 10 $\mathrm{mL}$, ditambah dengan $0,4 \mathrm{~mL}$ reagen Folin-Ciocalteu, dan dibiarkan selama 8 menit. 
Larutan selanjutnya ditambah $4 \mathrm{~mL} \mathrm{Na} \mathrm{CO}_{3} 7 \%$ dan ditambah aqua bidestilata sampai batas tanda. Setelah 2 jam, absorbansinya dibaca pada panjang gelombang $765 \mathrm{~nm}$. Sebagai blanko digunakan aqua bidestilata dan reagen Folin-Ciocalteu. Kandungan fenolik total dinyatakan sebagai gram ekivalen asam galat tiap 100 gram berat kering subfraksi (\% b/b EAG) (Chun et al., 2003).

\section{HASIL DAN PEMBAHASAN}

\section{Ekstraksi Daun Zodia}

Dalam penelitian ini, sampel daun zodia yang telah dikeringkan menjadi serbuk diekstraksi menggunakan metode maserasi. Kelebihan metode maserasi antara lain: alat yang digunakan dan cara pengerjaan yang sederhana, biaya operasional yang relatif rendah, dan dapat mencegah rusaknya senyawa-senyawa aktif yang bersifat termolabil atau tidak tahan panas (Savitri et al., 2017). Sampel ditimbang sebanyak $10 \mathrm{~g}$ selanjutnya dimaserasi menggunakan pelarut metanol sebanyak $4 \times 250 \mathrm{~mL}$. Proses maserasi dilakukan dengan perbandingan antara sampel dan pelarut sebesar 1:100. Pada waktu perendaman akan terjadi kontak antara sampel dan pelarut yang menyebabkan zat atau senyawa aktif yang terdapat dalam sampel akan tertarik ke dalam pelarut. Rendemen ekstrak daun zodia ditampilkan pada Tabel 1 .

Tabel 1. Rendemen ekstrak daun zodia

\begin{tabular}{llccc}
\hline Jenis ekstrak & Warna & Berat ekstrak (g) & Berat sampel (g) & $\begin{array}{c}\% \\
\text { Rendemen }\end{array}$ \\
\hline Ekstrak metanol & $\begin{array}{l}\text { Hitam } \\
\text { kehijauan }\end{array}$ & 0,50 & 10 & 5,0 \\
$\begin{array}{l}\text { Ekstrak etil } \\
\text { asetat }\end{array}$ & $\begin{array}{l}\text { kitam } \\
\text { kehijauan }\end{array}$ & 0,40 & 10 & 4,0 \\
$\begin{array}{l}\text { Ekstrak } \\
\text { diklorometana }\end{array}$ & $\begin{array}{l}\text { Hitam } \\
\text { kehijauan }\end{array}$ & 0,45 & 10 & 4,5 \\
\hline
\end{tabular}

Filtrat diuapkan menggunakan evaporator dengan tujuan untuk menguapkan pelarut metanol yang digunakan dalam proses maserasi sehingga diperoleh ekstrak pekat yang digunakan dalam uji antioksidan. Perlakuan yang sama untuk proses maserasi dengan menggunakan pelarut etil asetat yang ditargetkan dapat mengekstrak senyawa-senyawa aktif yang bersifat semipolar. Demikian juga untuk perlakuan yang sama pada pelarut diklorometana yang ditargetkan dapat mengekstrak senyawa-senyawa aktif yang bersifat non polar. 
Penyajian rendemen adalah perbandingan antara berat ekstrak yang diperoleh dengan sampel yang digunakan. Ekstrak metanol daun zodia mempunyai presentase rendemen terbanyak diikuti oleh ekstrak diklorometana dan ekstrak etil asetat. Hal tersebut menunjukkan bahwa kandungan senyawa yang terdapat didalam daun zodia paling banyak adalah senyawa yang bersifat polar, diikuti oleh senyawa-senyawa non polar dan semi polar.

\section{Uji Antioksidan menggunakan Metode DPPH}

Larutan uji yang digunakan pada uji antioksidan dengan metode DPPH terdiri dari ekstrak metanol, ekstrak etil asetat, dan esktrak diklorometana dari sampel serbuk daun zodia. Tujuan pembuatan ketiga larutan uji tersebut adalah untuk mengetahui aktivitas antioksidan terbaik yang ditunjukkan dengan nilai $\mathrm{IC}_{50}$ terkecil. Selain itu, dilakukan penentuan nilai $\mathrm{IC}_{50}$ dari antioksidan standar atau pembanding (Vitamin C) dengan tujuan untuk membandingkan potensi ekstrak daun zodia dengan antioksidan standar yang sudah terbukti potensi antioksidannya.

Metode DPPH mempunyai kelebihan jika dibandingkan dengan metode lain, yaitu metodenya sederhana, mudah, dan hanya membutuhkan sampel dan reagen yang sedikit dalam uji antioksidan. DPPH (1,1-difenil-2-pikrilhidrazil) adalah salah satu jenis radikal bebas sintetik yang berwarna ungu dan mempunyai atom nitrogen yang tidak berpasangan. Prinsip dasar dalam uji antioksidan menggunakan metode DPPH adalah adanya reaksi kimia antara senyawa antioksidan dan radikal bebas DPPH melalui mekanisme reaksi donasi atau pemberian atom hidrogen oleh senyawa antioksidan ke radikal bebas DPPH yang mengakibatkan adanya perubahan warna larutan dari ungu menjadi kuning atau dari ungu pekat menjadi ungu pudar. Perubahan warna tersebut menyebabkan penurunan nilai absorbansi sampel (Molyneux, 2004). Mekanisme reaksi antara DPPH dan atom H yang berasal dari antioksidan dapat dilihat pada Gambar 1.

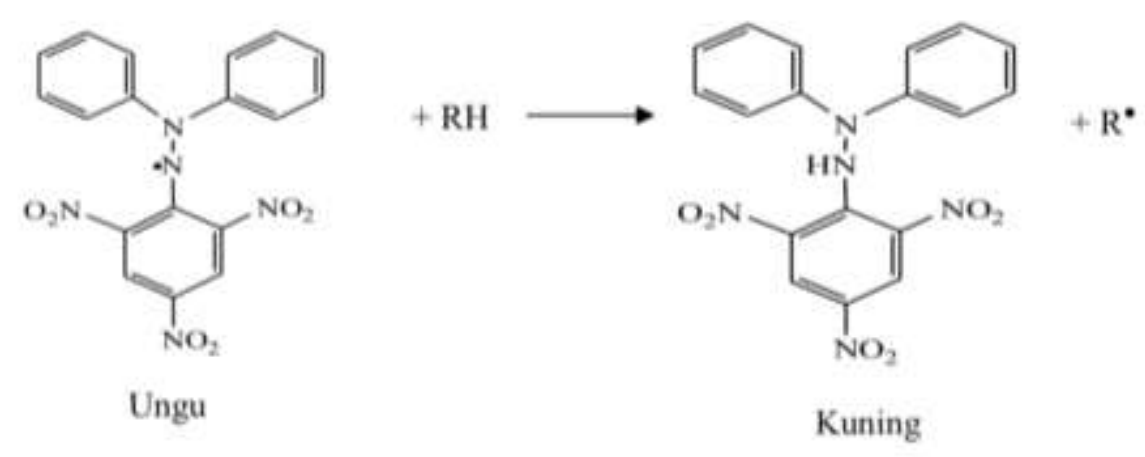

Gambar 1. Reaksi antara DPPH dan atom H yang berasal dari antioksidan (Molyneux, 2004). 
Dalam uji aktivitas antioksidan ini, digunakan perbandingan 20:1 yaiitu $5 \mathrm{~mL}$ larutan DPPH dicampur dengan 0,25 mL larutan sampel (ekstrak metanol, ekstrak etil asetat, ekstrak diklorometana daun zodia, dan vitamin C) pada tiap variasi konsentrasi larutan uji. Kesempurnaan reaksi antara larutan DPPH dan larutan uji dimaksimalkan dengan perlakuan vortex selama 1 menit. Persentase penghambatan dapat ditentukan dari adanya perbedaan serapan antara absorben sampel dan absorben kontrol yang diukur menggunakan spektrofotometer UV-Vis pada panjang gelombang $515 \mathrm{~nm}$. Hasil uji antioksidan menggunakan metode DPPH dari ekstrak metanol dan esktrak etil setat daun zodia ditunjukkan dalam Tabel 2 dan ekstrak diklorometana daun zodia ditunjukkan dalam Tabel 3.

Tabel 2. Hasil uji antioksidan menggunakan metode DPPH dari ekstrak metanol dan esktrak etil asetat daun zodia

\begin{tabular}{cccc}
\hline \multirow{2}{*}{$\begin{array}{c}\text { Konsentrasi } \\
(\mathbf{p p m})\end{array}$} & \multicolumn{3}{c}{ Persentase penghambatan terhadap radikal DPPH (\%) } \\
\cline { 2 - 4 } & Vitamin C & $\begin{array}{c}\text { Ekstrak metanol daun } \\
\text { zodia }\end{array}$ & $\begin{array}{c}\text { Ektrak etil asetat daun } \\
\text { zodiac }\end{array}$ \\
\hline 0 & 0 & 0 & 0 \\
20 & 31 & 8 & 9 \\
40 & 44 & 13 & 14 \\
60 & 58 & 20 & 19 \\
80 & 71 & 27 & 27 \\
100 & 83 & 29 & 45 \\
\hline
\end{tabular}

Table 3. Hasil uji antioksidan menggunakan metode DPPH dari ekstrak diklorometana daun zodia

\begin{tabular}{cc}
\hline Konsentrasi $(\mathbf{p p m})$ & Persentase penghambatan terhadap radikal DPPH $(\%)$ \\
\hline 0 & 0 \\
50 & 15 \\
100 & 25 \\
200 & 34 \\
300 & 46 \\
500 & 54 \\
\hline
\end{tabular}

Semakin besar konsentrasi larutan uji yang digunakan menyebabkan persentase penghambatan terhadap radikal DPPH juga semakin besar. Dengan demikian, konsentrasi larutan uji dan persentase penghambatan terhadap radikal DPPH mempunyai hubungan yang sebanding. Konsentrasi ekstrak diklorometana daun zodia yang digunakan untuk uji antioksidan secara in vitro jauh lebih besar jika dibandingkan dengan ekstrak metanol dan etil asetat daun zodia. Dengan demikian, ekstrak diklorometana membutuhkan konsentrasi yang besar untuk bisa menghasilkan persentase penghambatan terhadap radikal DPPH 
yang setara dengan ekstrak metanol dan ekstrak etil asetat daun zodia. Grafik hubungan antara konsentrasi ekstrak metanol dan esktrak etil asetat daun zodia dengan persentase penghambatan terhadap radikal DPPH ditunjukkan dalam Gambar 2 sedangkan grafik hubungan antara konsentrasi ekstrak diklorometana daun zodia dengan persentase penghambatan terhadap radikal DPPH ditunjukkan dalam Gambar 3.

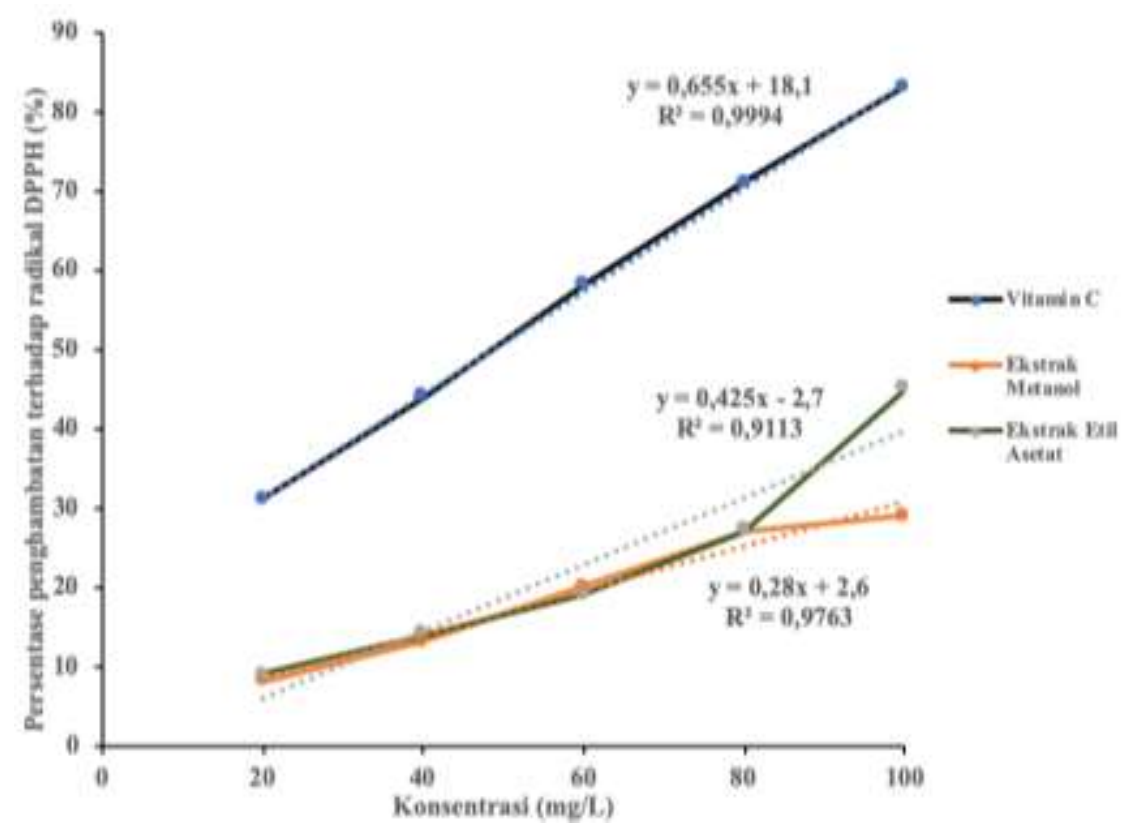

Gambar 2. Grafik hubungan antara konsentrasi ekstrak metanol dan esktrak etil asetat daun zodia dengan persentase penghambatan terhadap radikal DPPH

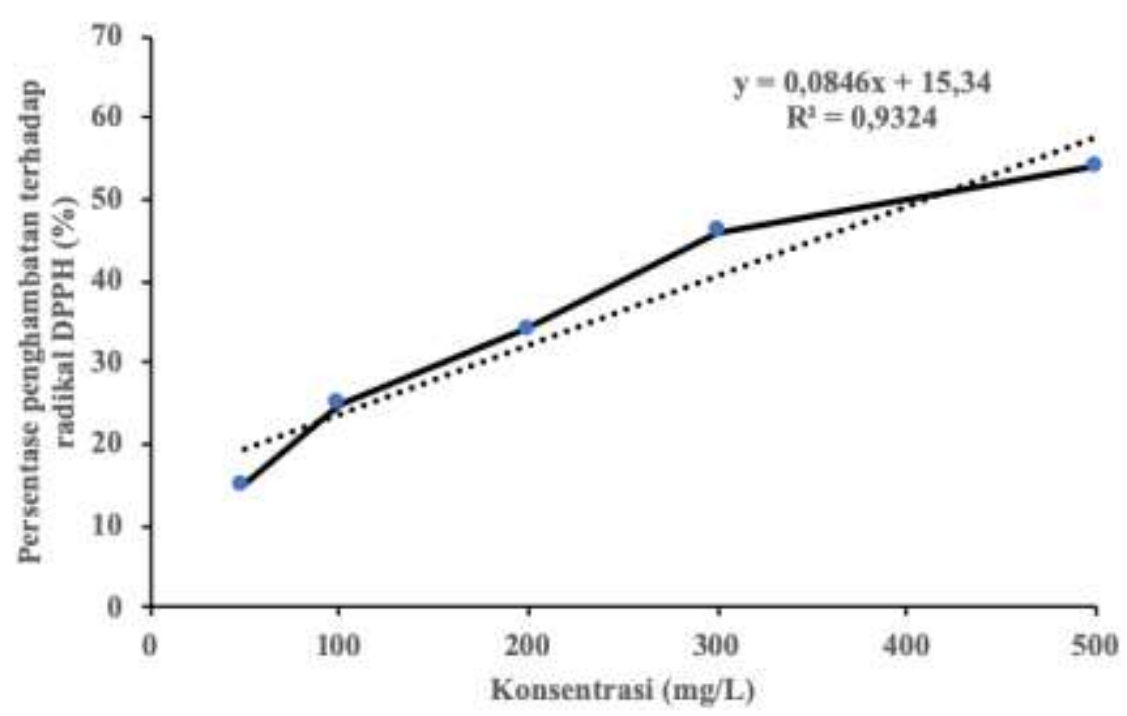

Gambar 3. Grafik hubungan antara konsentrasi ekstrak diklorometana daun zodia dengan persentase penghambatan terhadap radikal DPPH

$\mathrm{IC}_{50}$ adalah konsentrasi larutan dari sampel uji yang diperlukan untuk menghambat $50 \%$ radikal bebas $\mathrm{DPPH}$. Nilai $\mathrm{IC}_{50}$ dapat ditentukan dengan membuat grafik hubungan 
antara konsentrasi sampel (sumbu $\mathrm{x}$ ) dan persen penghambatan (sumbu y). Nilai IC $_{50}$ dihitung berdasarkan rumus persamaan regresi linear. Berdasarkan grafik hubungan antara konsentrasi larutan uji dengan persentase penghambatan terhadap radikal DPPH. Penentuan nilai $\mathrm{IC}_{50}$ dilakukan dengan cara memasukkan angka 50 ke dalam variabel y sehingga nilai $\mathrm{x}$ akan diketahui. Nilai $\mathrm{x}$ tersebut merupakan nilai $\mathrm{IC}_{50}$. Nilai $\mathrm{IC}_{50}$ dari ekstrak daun zodia ditampilkan pada Gambar 4.

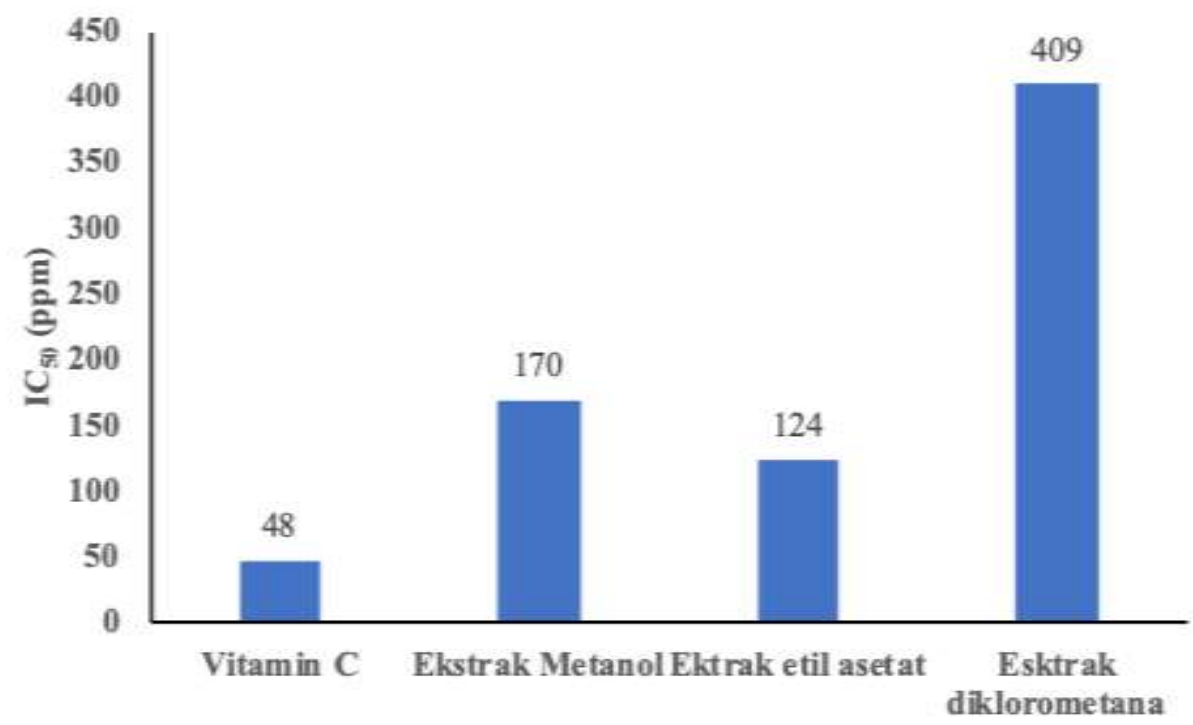

Gambar 4. Nilai $\mathrm{IC}_{50}$ dari ekstrak daun zodia.

Nilai IC $_{50}$ Vitamin $\mathrm{C}$ mempunyai aktivitas antioksidan yang sangat kuat (Molyneux, 2004). Berdasarkan penelitian yang lain juga menunjukkan bahwa vitamin C mempunyai aktivitas antioksidan yang sangat kuat ditunjukkan dengan nilai $\mathrm{IC}_{50}$ sebesar 12,24 $\mu \mathrm{g} / \mathrm{mL}$ atau 12,24 ppm (Egharevba et al., 2019); 9 ppm (Aoussar et al., 2020); 7,43 ppm (Paliwal et al., 2017); 8,15 ppm (Atere et al., 2018); 13,79 ppm (Setiawan and Febriyanti, 2017) dan 7,28 ppm (Karundeng et al., 2019). Perbedaan nilai IC $_{50}$ dari vitamin C tersebut disebabkan oleh beberapa hal, yaitu waktu inkubasi, panjang gelombang, konsentrasi DPPH, perbandingan volume larutan uji dan DPPH yang digunakan selama penelitian.

Ekstrak etil asetat daun zodia mempunyai nilai $\mathrm{IC}_{50}$ yang paling kecil diikuti dengan esktrak metanol dan ekstrak diklorometana daun zodia. Semakin kecil nilai $\mathrm{IC}_{50}$ suatu ekstrak menunjukkan bahwa ekstrak tersebut berpotensi kuat sebagai antioksidan. Ekstrak etil asetat daun zodia mempunyai potensi antioksidan yang masuk dalam kategori sedang sedangkan esktrak metanol dan ekstrak diklorometana daun zodia potensi antioksidan yang masuk dalam kategori kurang. Penelitian lain juga menunjukkan bahwa 
ekstrak etil asetat Evodia rutaecarpa mempunyai nilai $\mathrm{IC}_{50}$ yang lebih kecil daripada ekstrak aseton, air dan etanol Evodia rutaecarpa (Qin et al., 2012). Selain itu, bilai IC 50 dari ekstrak etil asetat kulit Evodia lunu-ankenda (Gaertn.) Merr. sebesar 16,55 $\pm 0,89$ ppm (potensi antioksidan sangat kuat) (Venkatachalam et al., 2009).

Di sisi lain, mungkin banyak penelitian yang menunjukkan bahwa ekstrak metanol dari suatu simplisia atau tanaman yang mempunyai aktivitas antioksidan yang terbaik (Pandey et al., 2017; Nandhakumar and Indumathi, 2013; Bera et al., 2015). Dalam penelitian tersebut mengklaim bahwa senyawa-senyawa fenolik yang aktif sebagai antioksidan banyak yang tertarik ke dalam pelarut metanol. Akan tetapi, dalam penelitian ini menunjukkan bahwa senyawa-senyawa fenolik yang dapat berpotensi sebagai antioksidan juga dapat terekstrak ke dalam pelarut etil asetat (semi polar). Senyawa fenolik telah mendapatkan perhatian luas karena fungsi fisiologisnya, termasuk antioksidan, efek anti-mutagenik, anti-karsinogenik, dan anti-inflamasi (Adebiyi et al., 2017). Kemampuan ekstrak etil asetat daun zodia sebagai antioksidan ini dikaitkan dengan kandungan senyawa fenolik yang terdapat dalam daun zodia, yang meliputi : a-curcumene dan vitamin E. Dua senyawa tersebut merupakan senyawa fenolik karena mempunyai struktur benzena yang mengikat gugus hidroksil. Dalam penelitian ini, juga dapat diketahui bahwa ekstrak diklorometana daun zodia menghasilkan aktivitas antioksidan yang sangat lemah, yaitu 409 ppm. Hal tersebut disebabkan pelarut diklorometana merupakan pelarut non polar sehingga senyawa-senyawa yang tertarik ke dalam pelarut adalah senyawa-senyawa non polar.

Secara umum, tingkat efek antioksidan dari ekstrak dapat dikaitkan dengan komposisi fenoliknya (Khadijah et al., 2017). Mekanisme kerja antioksidan dari suatu ekstrak adalah terjadinya reaksi antara senyawa antioksidan dalam suatu ekstrak yang mempunyai gugus fenolik dan radikal bebas DPPH melalui mekanisme pemberian atom hidrogen ke radikal bebas DPPH.

\section{Penentuan Kadar Fenolik Total}

Dalam penentuan kadar fenolik total dalam ekstrak daun zodia, digunakan larutan standar asam galat (GAE). Pemilihan asam galat sebagai larutan standar dikarenakan asam galat merupakan salah satu fenol alami, stabil, dan relatif murah apabila dibandingkan dengan jenik fenol lainnya (Ahmad et al., 2017). Banyak penelitian yang juga menggunakan asam galat sebagai larutan standar dalam penentuan kadar fenolik total (Sabir et al., 2017; Uslu and Özcan, 2017). Reaksi antara asam galat dan reagen FolinCiocalteu ditunjukkan dalam Gambar 5. 


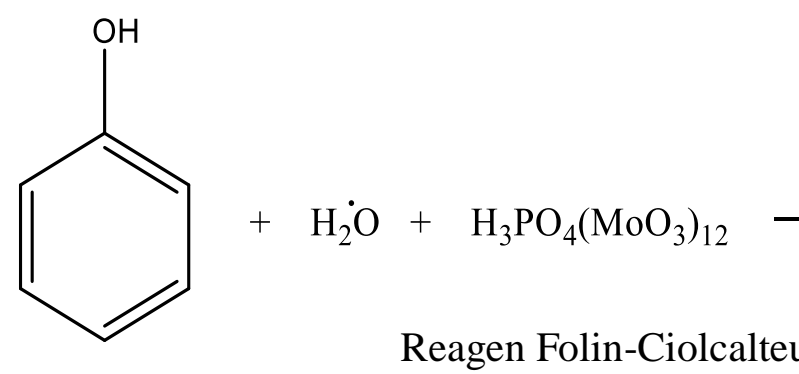

Senyawa fenol

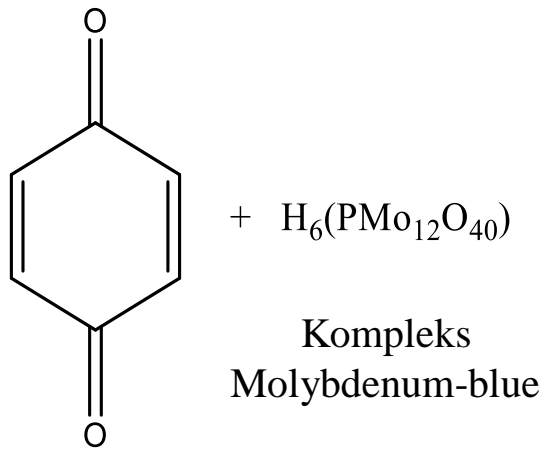

Kuinon

Gambar 5. Reaksi antara asam galat dan reagen Folin-Ciocalteu (Ford et al., 2019).

Reaksi antara asam galat dan reagen Folin-Ciocalteu akan menghasilkan larutan yang berwarna kuning yang menunjukkan bahwa ekstrak mengandung senyawa fenol. Mekanisme reaksinya adalah gugus fenolik-hidroksi mereduksi asam heteropoli (fosfomolibdat-fosfotungstat) yang terkandung dalam pereaksi Folin Ciocalteau menjadi suatu kompleks molibdenum-tungsten (Alfian and Susanti, 2013). Selanjutnya, ditambahkan dengan larutan $\mathrm{Na}_{2} \mathrm{CO}_{3}$ dan mengubah warna larutan menjadi biru yang dapat diukur absorbansinya pada panjang gelombang $765 \mathrm{~nm}$ (Ahmad et al., 2017). Senyawa fenolik hanya dapat bereaksi dengan reagen Folin-Ciocalteu dalam suasana basa agar terjadi disosiasi proton pada senyawa fenolik menjadi ion fenolat sehingga perlu ditambahkan larutan $\mathrm{Na}_{2} \mathrm{CO}_{3}$. Semakin besar kadar fenolik total dalam suatu esktrak mengakibatkan semakin banyak jumlah ion fenolat yang akan mereduksi asam heteropoli (fosfomolibdat-fosfotungstat) menjadi kompleks molibdenum-tungsten yang menyebabkan warna biru yang dihasilkan menjadi semakin pekat (Alfian and Susanti, 2013). Kurva kalibrasi asam galat ditunjukkan dalam Gambar 6.

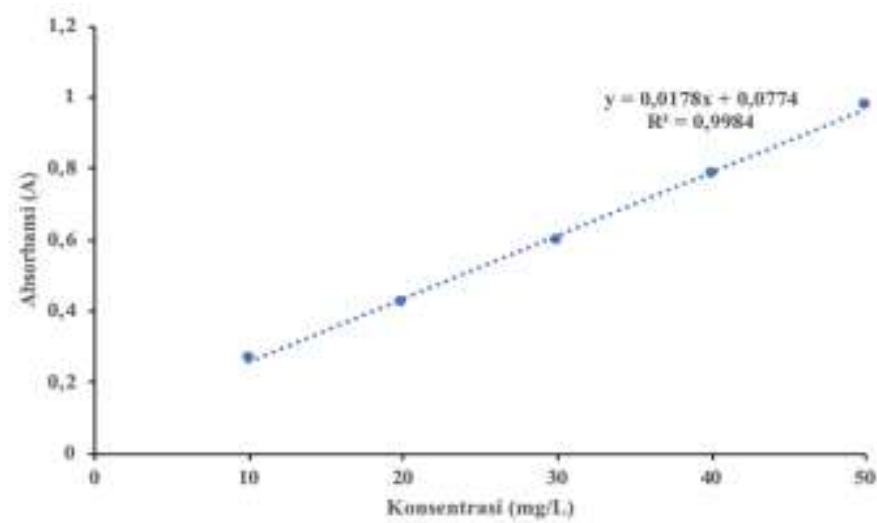

Gambar 6. Kurva kalibrasi asam galat. 
Kurva kalibrasi dengan persamaan regresi untuk absorbasi asam galat pada konsentrasi 10, 20, 30, 40 dan 50 ppm sebesar $\mathrm{y}=0,0178 \mathrm{x}+0,0774$ dengan nilai koefisien korelasi (r) sebesar 0,9984. Hubungan antara konsentrasi dan absorbansi asam galat adalah linear yang ditunjukkan dengan nilai $r$ yang mendekati angka 1. Persamaan kurva kalibrasi tersebut digunakan dalam penentuan kadar fenolik total dari ekstrak daun zodia yang ditunjukkan dalam Tabel 4 .

Tabel 4. Kadar fenolik total ekstrak daun zodia

\begin{tabular}{lcccc}
\hline Ekstrak pekat & Absorbansi & $\begin{array}{c}\text { Fenolik total } \\
(\mathbf{m g} / \mathbf{m L})\end{array}$ & $\begin{array}{c}\text { Fenolik total } \\
(\mathbf{m g ~ G A E} / \mathbf{g})\end{array}$ & $\begin{array}{c}\text { Fenolik total } \\
(\mathbf{\%})\end{array}$ \\
\hline Metanol & 0,51 & 0,02430 & 0,02430 & 2,43 \\
Etil asetat & 0,288 & 0,01183 & 0,01183 & 1,18 \\
Diklorometana & 0,243 & 0,00930 & 0,00930 & 0,93 \\
\hline
\end{tabular}

Kadar fenolik total yang paling banyak terdapat dalam ekstrak metanol daun zodia kemudian diikuti oleh ekstrak etil asetat dan ekstrak diklorometana. Fenol adalah senyawa yang memiliki kemampuan untuk menghancurkan radikal karena mengandung gugus hidroksil. Komponen tanaman penting ini melepaskan atom hidrogen dari gugus hidroksilnya menjadi radikal dan membentuk radikal fenoksil yang stabil; karenanya, mereka memainkan peran penting dalam aktivitas antioksidan. Oleh karena itu, penentuan jumlah senyawa fenolik sangat penting untuk menentukan kapasitas antioksidan dari ekstrak tanaman (Bajalan et al., 2017). Korelasi nilai IC $_{50}$ dan kadar fenolik ekstrak daun zodia ditampilkan pada Gambar 7.

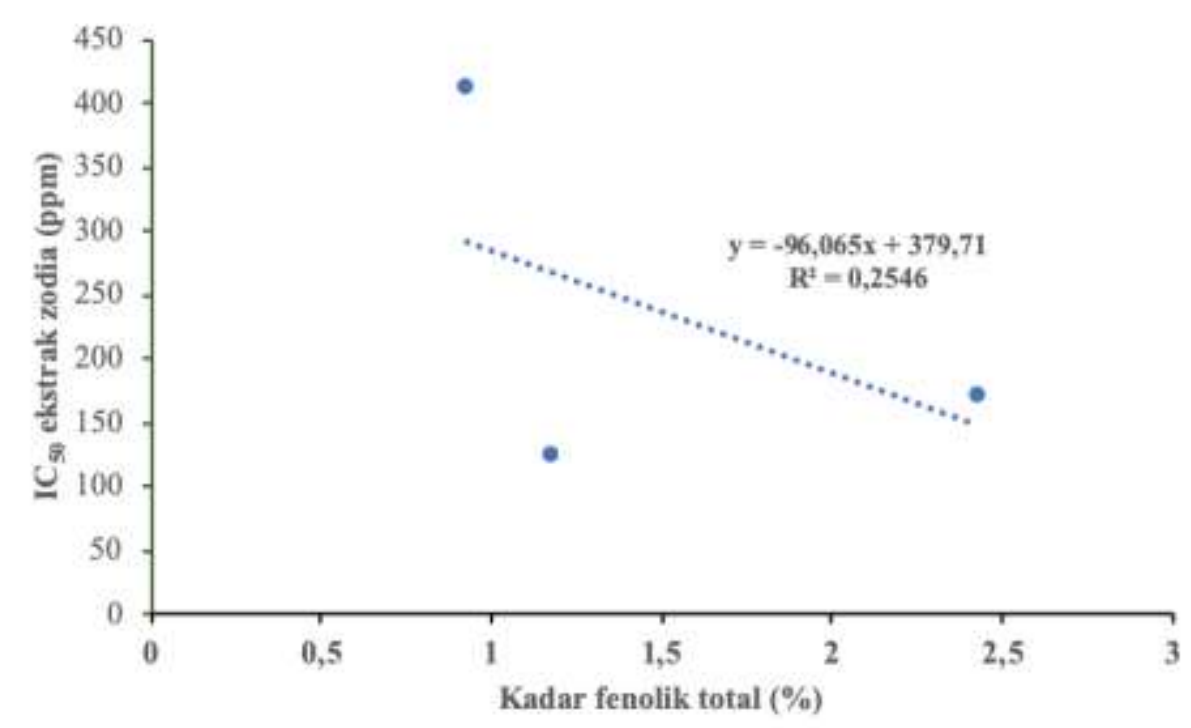

Gambar 7. Korelasi nilai $\mathrm{IC}_{50}$ dan kadar fenolik ekstrak daun zodia. 
Korelasi nilai $\mathrm{IC}_{50}$ dan kadar fenolik ekstrak daun zodia dianalisis untuk mengetahui hubungan antara kadar fenolik total dan aktivitas antioksidan. Nilai $r$ yang diperoleh adalah sebesar 0,256 dimana nilai tersebut sangat jauh dari nilai 1 . Hal tersebut menunjukkan bahwa semakin besar kadar fenolik total dalam ekstrak daun zodia tidak mempengaruhi aktivitas antioksidan. Banyak penelitian yang berhasil membuktikan ada korelasi atau hubungan linear antara kadar total fenolik dengan aktivitas antioksidan (Benabdallah et al., 2016; Abootalebian et al., 2016); (Chavan et al., 2013). Di sisi lain, juga banyak penelitian bahwa aktivitas antioksidan yang bagus tidak selalu berkaitan dengan kadar fenolik total dalam esktrak (Alaklabi et al., 2018); (Muniyandi et al., 2019). Dengan demikian, aktivitas antioksidan tidak hanya dipengaruhi oleh kadar fenolik total, tetapi juga jenis senyawa aktif yang terkandung dalam suatu ekstrak tersebut (Hossain et al., 2011).

\section{KESIMPULAN}

Daun zodia (Evodia suaveolens) diekstraksi secara maserasi menggunakan variasi 3 pelarut, yaitu: metanol, etil asetat, dan dikorometana selanjutnya dilakukan uji aktivitas antioksidan menggunakan metode DPPH. Nilai aktivitas antioksidan yang dinyatakan dengan $\mathrm{IC}_{50}$ dari ekstrak metanol, etil asetat, dan diklorometana dari daun zodia berturutturut adalah 170, 124, dan 409 ppm. Kadar fenolik total dari ekstrak metanol, etil asetat, dan diklorometana dari daun zodia berturut-turut adalah 0,02430; 0,01183; dan 0,00930 $\mathrm{mg} \mathrm{GAE} / \mathrm{g}$.

\section{UCAPAN TERIMAKASIH}

Terima kasih disampaikan kepada Direktorat Jenderal Penguatan Riset dan Pengembangan Kementerian Riset, Teknologi dan Pendidikan Tinggi Tahun Anggaran 2019 yang telah mendanai Penelitian Dosen Pemula (PDP) ini dengan Kontrak Penelitian Nomor: 068/SP2H/LT/MONO/L7/2019.

\section{DAFTAR PUSTAKA}

Abootalebian, M., Keramat, J., Kadivar, M., Ahmadi, F., and Abdinian, M., 2016. Comparison of Total Phenolic and Antioxidant Activity of Different Mentha spicata and M. longifolia accessions. Annals of Agricultural Sciences 61 (2), 175179.

Adebiyi, O. E., Olayemi, F. O., Ning-Hua, T., and Guang-Zhi, Z., 2017. In Vitro Antioxidant Activity, Total Phenolic and Flavonoid Contents of Ethanol Extract of 
Stem and Leaf of Grewia carpinifolia. Beni-Suef University Journal of Basic and Applied Sciences 6 (1), 10-14. doi: 10.1016/j.bjbas.2016.12.003.

Ahmad, A. R., Juwita, J., Ratulangi, S. A. D., and Malik, A., 2017. Penetapan Kadar Fenolik dan Flavonoid Total Ekstrak Metanol Buah dan Daun Patikala (Etlingera elatior (Jack) RM SM). Pharmaceutical Sciences and Research (Psr) 2 (1), 1-10.

Aktumsek, A., Zengin, G., Guler, G. O., Cakmak, Y. S., and Duran, A., 2013. Antioxidant Potentials and Anticholinesterase Activities of Methanolic and Aqueous Extracts of Three Endemic Centaurea L. species. Food and Chemical Toxicology 55, 290-296. doi: 10.1016/j.fct.2013.01.018.

Alaklabi, A., Arif, I. A., Ahamed, A., Kumar, R. S., and Idhayadhulla, A., 2018. Evaluation of Antioxidant and Anticancer Activities of Chemical Constituents of the Saururus chinensis root extracts. Saudi Journal of Biological Sciences 25 (7), 1387-1392

Alfian, R., and Susanti, H., 2013. Penetapan Kadar Fenolik Total Ekstrak Metanol Kelopak Bunga Rosella Merah (Hibiscus sabdariffa Linn) dengan Variasi Tempat Tumbuh Secara Spektrofotometri. Pharmaciana 2 (1), 73-80.

Aoussar, N., Rhallabi, N., Mhand, R. A., Manzali, R., Bouksaim, M., Douira, A., and Mellouki, F., 2020. Seasonal Variation of Antioxidant Activity and Phenolic Content of Pseudevernia furfuracea, Evernia prunastri and Ramalina farinacea from Morocco. Journal of the Saudi Society of Agricultural Sciences 19 (1), 1-6.

Atere, T. G., Akinloye, O. A., Ugbaja, R. N., Ojo, D. A., and Dealtry, G., 2018. In Vitro Antioxidant Capacity and Free Radical Scavenging Evaluation of Standardized Extract of Costus afer leaf. Food Science and Human Wellness 7 (4), 266-272.

Bajalan, I., Zand, M., Goodarzi, M., and Darabi, M., 2017. Antioxidant Activity and Total Phenolic and Flavonoid Content of the Extract and Chemical Composition of the Essential Oil of Eremostachys laciniata collected from Zagros. Asian Pacific Journal of Tropical Biomedicine 7 (2), 144-146.

Benabdallah, A., Rahmoune, C., Boumendjel, M., Aissi, O., and Messaoud, C., 2016. Total Phenolic Content and Antioxidant Activity of Six Wild Mentha Species (Lamiaceae) from Northeast of Algeria. Asian Pacific journal of Tropical Biomedicine 6 (9), 760-766.

Bera, T. K., Chatterjee, K., and Ghosh, D., 2015. In-Vitro Antioxidant Properties of the Hydro-Methanol Extract of the Seeds of Swietenia mahagoni (L.) Jacq. Biomarkers and Genomic Medicine 7 (1), 18-24.

Chavan, J. J., Gaikwad, N. B., Kshirsagar, P. R., and Dixit, G. B., 2013. Total Phenolics, Flavonoids and Antioxidant Properties of Three Ceropegia Species from Western Ghats of India. South African Journal of Botany 88, 273-277.

Chun, O. K., Kim, D. O., and Lee, C. Y., 2003. Superoxide Radical Scavenging Activity of the Major Polyphenols in Fresh Plums. Journal of Agricultural and Food Chemistry 51 (27), 8067-8072.

Egharevba, G. O., Dosumu, O. O., Oguntoye, S. O., Njinga, N. S., Dahunsi, S. O., Hamid, A. A., and Ujjukuri, P., 2019. Antidiabetic, Antioxidant and Antimicrobial Activities of Extracts of Tephrosia bracteolata leaves. Heliyon 5 (8), 1-6. 
Ford, L., Theodoridou, K., Sheldrake, G. N., \& Walsh, P. J., 2019. A Critical Review of Analytical Methods Used for The Chemical Characterisation and Quantification of Phlorotannin Compounds in Brown Seaweeds. Phytochemical Analysis 30 (6), 587599. doi: 10.1002/pca.2851.

Handayani, P. A., and Nurcahyanti, H., 2014. Ekstraksi Minyak Atsiri Daun Zodia (Evodia suaveolens) dengan Metode Maserasi dan Distilasi Air. Jurnal Bahan Alam Terbarukan 3 (1), 1-7. doi: 10.15294/jbat.v3i1.3095.

Hidayati, M. D., Ersam, T., Shimizu, K., and Fatmawati, S., 2017. Antioxidant Activity of Syzygium polyanthum Extracts. Indonesian Journal of Chemistry 17 (1), 49-53.

Hossain, M. A., Shah, M. D., Gnanaraj, C., and Iqbal, M., 2011. In Vitro Total Phenolics, Flavonoids Contents and Antioxidant Activity of Essential Oil, Various Organic Extracts from The Leaves of Tropical Medicinal Plant Tetrastigma from Sabah. Asian Pacific Journal of Tropical Medicine 4 (9), 717-721.

Isrianto, P. L., 2016. Bisnis Usaha Perbanyakan Tanaman Zodia (Evodia suaveolens) sebagai Tanaman Pengusir Nyamuk di Kota Surabaya. Inovasi XVIII (2), 102-109.

Karundeng, G., Simbala, H., and Jayanto, I., 2019. Identifikasi Fitokimia, Uji Aktivitas Antioksidan dengan Metode 1.1-diphenyl-2-picrylhydrazyl (DPPH), dan Toksisitas dengan Metode Brine Shrimp Lethality Test (BSLT) dari Ekstrak Etanol Tangkai Buah Pinang Yaki (Areca vestiaria Giseke). PHARMACON 8 (3), 205-214.

Khadijah, K., Jayali, A. M., Umar, S., and Sasmita, I., 2017. Penentuan Total Fenolik Dan Aktivitas Antioksidan Ekstrak Etanolik Daun Samama (Anthocephalus macrophylus) Asal Ternate, Maluku Utara. Jurnal Kimia Mulawarman 15 (1), 1118.

Lestari, M. S., Himawan, T., Abadi, A. L., and Retnowati, R., 2015. Toxicity and Phytochemistry Test of Methanol Extract of Several Plants from Papua Using the Brine Shrimp Lethality Test (BSLT). Journal of Chemical and Pharmaceutical Research 7 (4), 866-872.

Liu, J., Jia, L., Kan, J., and Jin, C. H., 2013. In Vitro and in Vivo Antioxidant Activity of Ethanolic Extract of White Button Mushroom (Agaricus bisporus). Food and Chemical Toxicology 51, 310-316. doi: 10.1016/j.fct.2012.10.014.

Molyneux, P., 2004. The Use of the Stable Free Radical Diphenylpicrylhydrazyl (DPPH) for Estimating Antioxidant Activity. Songklanakarin Journal of Science and Technology 26 (2), 211-219.

Muniyandi, K., George, E., Sathyanarayanan, S., George, B. P., Abrahamse, H., Thamburaj, S., and Thangaraj, P., 2019. Phenolics, Tannins, Flavonoids and Anthocyanins Contents Influenced Antioxidant and Anticancer Activities of Rubus Fruits from Western Ghats, India. Food Science and Human Wellness 8 (1), 73-81.

Nandhakumar, E., and Indumathi, P., 2013. In Vitro Antioxidant Activities of Methanol and Aqueous Extract of Annona squamosa (L.) Fruit Pulp. Journal of Acupuncture and Meridian Studies 6 (3), 142-148.

Paliwal, S. K., Sati, B., Faujdar, S., and Sharma, S., 2017. Antioxidant and Antibacterial Activities of Various Extracts of Inula cuspidata CB Clarke stem. Beni-Suef University Journal of Basic and Applied Sciences 6 (2), 97-105. doi: 10.1016/j.bjbas.2016.10.003. 
Pandey, B. P., Thapa, R., and Upreti, A., 2017. Chemical Composition, Antioxidant and Antibacterial Activities of Essential Oil and Methanol Extract of Artemisia vulgaris and Gaultheria fragrantissima Collected from Nepal. Asian Pacific Journal of Tropical Medicine 10 (10), 952-959.

Porkony, J., Yanishlieva, N. and Gordon, M., 2001. Introduction of Antioxidant, Antioxidants in food: Practical applications. Elsevier, New. York. doi: 10.1007/s13398-014-0173-7.2.

Qin, W., Zou, B., Zhang, Y., Cheng, Z., and HUI, X., 2012. Free Radical Scavenging Activities of the Extracts from Evodia rutaecarpa. Asian Journal of Chemistry 24 (6). 2503-2505.

Sabir, S. M., Athayde, M. L., Boligon, A. A., and Rocha, J. B. T., 2017. Antioxidant Activities and Phenolic Profile of Baccharis trimera, A Commonly Used Medicinal Plant from Brazil. South African Journal of Botany 113, 318-323.

Sanora, G. D., Mastura, E. Y., Handoyo, M. O. M., and Purnama, E. R., 2019. Identification of Anticancer Active Compound from GC-MS Test Results of Zodia Leaves (Evodia suaveolens) Ethanol Extract. Jurnal Biota 5 (2), 89-95.

Setiawan, N. C. E., and Febriyanti, A., 2017. Aktivitas Antioksidan Ekstrak Etanol dan Fraksi-Fraksi Umbi Eleutherine palmifolia (L.) Merr dengan Metode DPPH. Journal of Current Pharmaceutical Sciences 1 (1), 1-5.

Savitri, I., Suhendra, L., and Wartini, N. M., 2017. Pengaruh Jenis Pelarut pada Metode Maserasi Terhadap Karakteristik Ekstrak Sargassum polycystum. Jurnal Rekayasa dan Manajemen Agroindustri 5 (3), 93-101.

Uslu, N., and Özcan, M. M., 2019. Effect of Microwave Heating on Phenolic Compounds and Fatty Acid Composition of Cashew (Anacardium occidentale) Nut and Oil. Journal of the Saudi Society of Agricultural Sciences 18 (3), 344-347.

Venkatachalam, T., Kumar, V. K., Kumar, P. S., Kalaiselvi, P., Chitra, M., and Kumar, N. S., 2009. In-vitro Antioxidant and Antimicrobial Activities of Ethyl Acetate Extract of Evodia lunu-Ankenda (Gaertn) Merr. Bark. Research Journal of Pharmacognosy and Phytochemistry 1 (3), 201-203.

Zou, Y., Lu, Y., and Wei, D., 2004. Antioxidant Activity of a Flavonoid-Rich Extract of Hypericum perforatum L. in Vitro. Journal of Agricultural and Food Chemistry 52 (16), 5032-5039. 